DOI 10.37882/2223-2982.2021.01-2.12

\title{
КОММУНИКАТИВНЫЕ ИМПЛИКАТУРЫ РУССКОГО ЯЗЫКА (НА ПРИМЕРЕ КОММУНИКАЦИИ В СОЦИАЛЬНЫХ СЕТЯХ И БЛОГАХ)
}

\section{CONVERSATIONALS IMPLICATURES OF THE RUSSIAN LANGUAGE (ON THE EXAMPLE OF COMMUNICATION IN SOCIAL NETWORKS AND BLOGS) \\ G. Petrosyan}

Summary: This article examines the problem of discretionary influence of the conversationals implicatures of the Russian language on the consciousness of virtual recipients who communicate in social networks and blogs. Popular blogs, accounts, and groups act as facilitators between users to whom a particular content is addressed, thereby aggregating new forms and types of postulates of speech communication. At the same time, modern communication in the Internet space is characterized by a desire to save speech resources, use conventional meanings of words and all their referents in order to make communication more transparent, which determined the appearance of various kinds of implicatures.

Keywords: conversationals implicatures, social networks, blog, virtual communication, information and psychological warfare.

\author{
Петросян Гаяне Оганесовна \\ К.филол.н., Старший преподаватель, РУДН \\ 11ga1978@mail.ru
}

Аннотация: В данной статье исследуется проблематика дискреционного влияния коммуникативных импликатур русского языка на сознание виртуальных реципиентов, коммуникатирующих в социальных сетях и блогах. Популярные блоги, аккаунты и группы выступают в роли фасилитаторов между пользователями, которым адресован тот или иной контент, агрегируя, тем самым новые формы и виды постулатов речевой коммуникации. При этом современное общение в Интернет-пространстве характеризуется стремлением к экономии речевых средств, использованию конвенциональных значений слов и всех их референтов с целью сделать коммуникацию более транспарентной, что детерминировало появление различного рода импликатур.

Ключевые слова: коммуникативная импликатура, социальные сети, блог, виртуальная коммуникация, информационно-психологическая война.

Если в 2004 году появилась первая социальная сеть, позволяющая общаться вне профессиональных (в т.ч. военных) целей и насчитывала единицы реципиентов, то в настоящий момент (2020 год) охват россиян, имеющих активные аккаунты, достиг нескольких тысяч пользователей (см. рис. 1).

При этом существуют спецслужбы (модераторы контента), отслеживающие информацию деструктивного, компрометирующего, недостоверного характера с целью ее ликвидации. Это осуществляется преимущественно посредством хештегов и других инструментов. Поэтому для того, чтобы информация не была заблокированной или удаленной из сети, а стала доступной как можно большему числу пользователей, адресанты активно используют коммуникативные импликатуры, позволяя избегать эксплицитности высказывания и, тем самым, уклоняясь от наказаний со стороны компетентных служб.

Благодаря своей имплицитности, коммуникативные импликатуры являются эффективным методом общения, поэтому способны выступать в роли стратегического оружия в социальных сетях и блогах, призывая население к тем или иным действиям/бездействию, выполняя, 


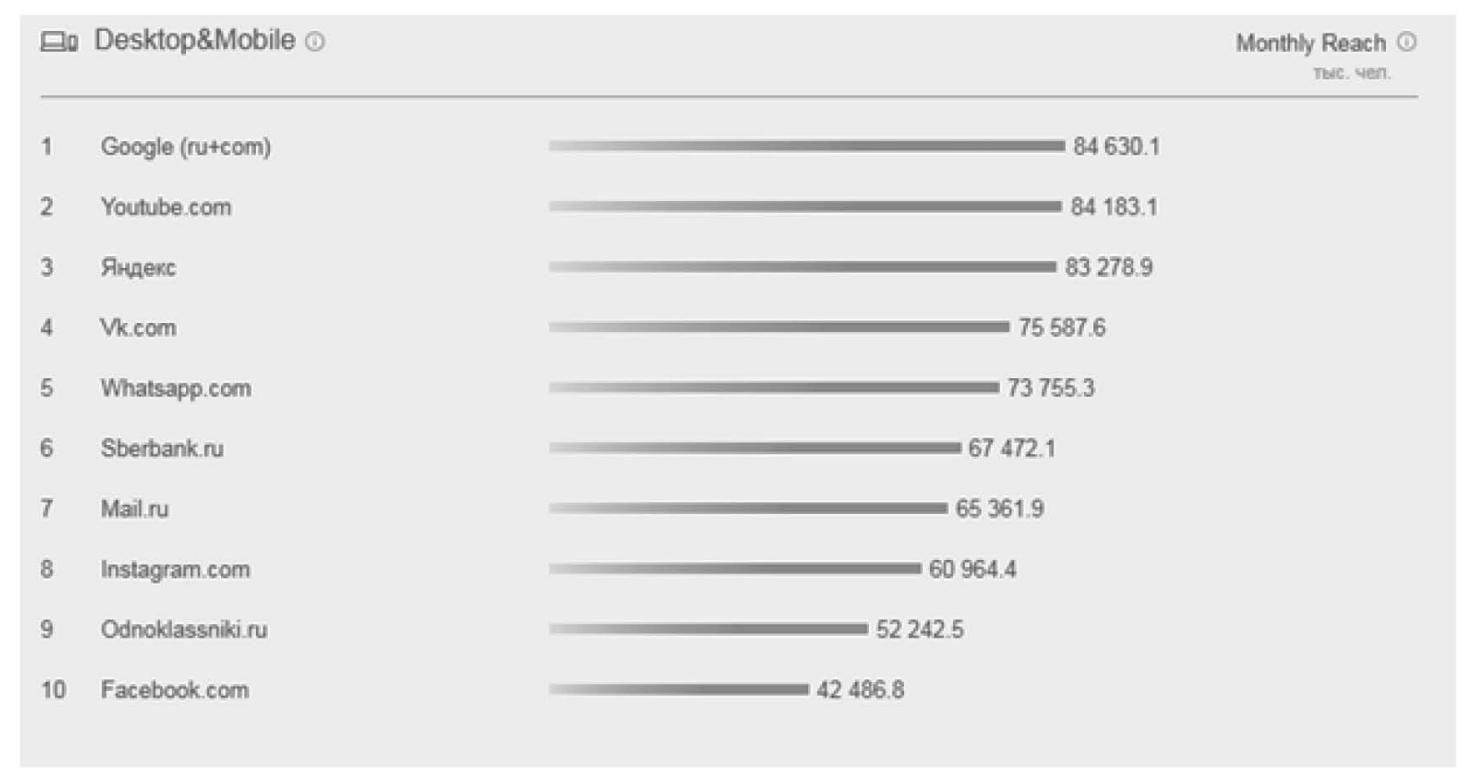

Рис. 1. Количество человек, заходящих хотя бы 1 раз за месяц в социальную сеть. Апрель, 2020 год [19]

тем самым, определенные задачи, обусловленные целеполаганием информационной войны.

Напомним, что одним из самых эффективных оружий в эпоху глобализации, технологизации и информатизации общества являются СМИ и Интернет-контент. Исходя из исследований Н.П. Араповой (2007), информационнопсихологическая война является альтернативным способом «насильственного упорядочивания общественных взаимоотношений, вызванным проецированием традиционных военно-политических отношений на реалии информационного общественного устройства и, непосредственно, социума» [1, с. 37], «достижение психологического эффекта», - полагает А.А. Гостев (2017), - «ведётся посредством информационных/дезинформационных атак... на системы индивидуального, группового и общественного сознания..., и на поведение социальных общностей, включая целые народы и государства»[2, с. 56].

«Информационная Война (или кибервойна - прим. автора) - это коммуникационный социальный конфликт в информационном пространстве» $[22$, р. 1]. По мнению K. Giles (2015), каналы и методы кибервойны охватывают широкий спектр инструментов, включая компьютеры, смартфоны, реальные или придуманные средства массовой информации (далее - СМИ), заявления лидеров или знаменитостей, онлайн-кампании троллей, текстовые сообщения, vох рорs заинтересованных граждан (т.е. мнения людей, их неофициально записанные разговоры в общественных местах), видео на YouTube или прямые подходы к отдельным «живым мишеням» $[16$, р. 4].

Импликативная интенция адресанта вполне может быть ориентирована на решение более серьезных стратегических и тактических задач: формирование како- го-либо мнения в отношении конкретного предмета / объекта посредством виртуальной коммуникации. Так, согласно концепции И.А. Шаронова (2008), «коммуникативные импликатуры, которые представляют из себя отклонения от предполагаемой оценки предмета речи ради соблюдения основных принципов общения, играют особую роль в мейотически маркированной коммуникации» [8, с. 219].

Грайс (Paul Herbert Grice) «выделяет два класса импликатур - конвенциональные и речевые, отличающиеся механизмами порождения» [4, с. 84]. Для коммуникативных импликатур (т.е. разговорных, англ. - conversationals implicatures) характерен небуквальный смысл сказанного, часто, с имплицитным значением, интерпретируемым адресатом «на свое усмотрение», т.е. реципиент самостоятельно делает вывод относительно того, что адресант хотел до него донести тем или иным высказыванием.

Как отмечает в своих исследованиях Грайс, «исключительная интерпретация - это обобщенная коммуникативная импликатура» [18]. В то время как при прямой коммуникации общение происходит с использованием невербальных средств, включая мимику, жесты, интонацию и когнитивную базу того или иного национально-лингвокультурного сообщества (общие фоновые знания), выступающие в роли пресуппозиции текста, что делает общение более понятым и транспарентным, виртуальный дискурс в социальных сетях часто исключает данные презумпции, обеспечивая необходимый семантический компонент и наличие смысла в высказываниях посредством знания конвенциональных значений используемых слов и их референтов, контекста высказывания и эмоджи (англ, етојі - графического языка и пиктограмм, используемых в письменных текстах для 
обозначения эмоций).

D. Wilson \& D. Sperber (1981) полагают, что Грайс пытался создать рамки, в которые можно было бы вписать каждый аспект интерпретации высказывания. Учёный делал большой акцент на различии между тем, что сказано фактически, и тем, что подразумевается имплицитно, предполагая, что каждый аспект интерпретации может быть отнесен к той или иной категории. При этом $D$. Wilson \& D. Sperber (1981) подчеркивают, следующее: что говорится (какую пропозицию высказывания необходимо выразить), в значительной степени определяется лингвистическим правилом, в то время как то, что подразумевается, преимущественно детерминируется социальными и другими максимами [23, с. 156].

По мнению R. Carston \& A. Hall (2016), отличия дефиниций «экспликатура» и «импликатура» являются одним из проявлений различий между эксплицитным содержанием высказывания и его имплицитным значением. В некоторых «минималистских» подходах эксплицитное и имплицитное различия приравниваются к семантическому и прагматическому отличиям, т.е. к концепции Грайса. Однако понятие «экспликатура», принадлежащее к прагматической структуре теории релевантности, имеет более тесные связи с широкой «контекстуальной» перспективой, согласно которой контекстно-зависимые прагматические процессы вносят гораздо больший вклад в эксплицитно передаваемое предложение, чем просто разрешение двусмысленностей и предоставление референтов для индексаций. Важно отметить, что существуют прагматические процессы обогащения и корректировки смысла, которые не имеют лингвистического мандата, но полностью мотивированы соображениями значимости коммуникативной. Итак, (1) эксплицитное содержание высказывания может включать компоненты, которые не артикулируются в лингвистической форме сообщения, и (2) некоторые импликации Грайса - компоненты эксплицитно сообщаемого содержания, обусловленного истиной [14, с. 1]. При этом 3.К. Темиргазина (2015) акцентирует внимание на том, что «коммуникативные импликатуры не входят в собственно языковое эксплицитное (буквальное) содержание высказывания и могут иметь неконвенциональный характер» $[9$, с. 85].

В прагматике понятие «коммуникативная импликатура» интерпретируется R. Nordquist (2020) как косвенный или имплицитный речевой акт: то, что подразумевается под высказыванием говорящего, которое не является частью того, что явно сказано. Данный термин также известен как «импликатура» и выступает в роли антонима дефиниции «экспликатура» (т.е. явно сообщаемого постулата) [20]. Согласно исследованиям J. Moeschler (2012), в последние 20 лет концепция импликативных форм стала стержневой теорией нового прагматиче- ского взгляда на смысл дискурса. При этом дефиниция «импликатура» определяется учёным, как новый способ описания значения [19].

Коммуникативные импликатуры - это прагматические умозаключения, которые, в отличие от подтекстов и пресуппозиций, не привязаны к конкретным словам и фразам в высказывании, а возникают из контекстуальных факторов и понимания того, что в разговоре соблюдаются условности (Gricean, 2016) [17, с. 1]. Неограйсовская прагматика (Neo-Gricean pragmatics), - подчеркивает в своём исследовании R. Rooy (2003), стремится свести максимы разговора Грайса к так называемым принципам $Q$ и I, используемые для объяснения многих коммуникативных импликатур. Q-принцип (реализация первой максимы Грайса о количестве) «рекомендует» адресанту говорить столько, сколько он может, чтобы выполнить свои коммуникативные намерения, в то время как l-принцип (реализация второй максимы Грайса, за исключением качества) советует коммуниканту говорить не больше, чем он должен, чтобы выполнить эти цели. Оба принципа помогают усилить то, что сообщается в высказывании. Q-принцип подразумевает, что говорящий не намеревался сообщить противоположное и более сильное в информационном отношении высказывание. Данный принцип является метаязыковым и объясняет, как скалярные, так и клаузальные импликатуры [21, р. 284]. Полагаем, Q и I-принципы часто используются при виртуальном общении.

Так как современное общество регулярно использует для общения Интернет, в настоящее время в виртуальном пространстве блогов и социальных сетей присутствует огромное количество коммуникативных импликатур, которые можно условно дифференцировать на: бытовые, политические, медицинские (эпидемиологические), педагогические, научные, развлекательные, оппозиционные, компрометирующие, социальные, «экологические», деструктивные (с целью завлечения в секту или деструктивные игры / группы смерти, например, «Синий кит»), хейтерские, религиозные, PR-компании и/или черный PR и пр., при этом их (коммуникативные импликатуры) также релевантно декомпозировать на благоприятно и неблагоприятно воздействующие на психоэмоциональный фон и умонастроения реципиентов, вплоть до когнитивных процессов пользователей. Нами создана схема, определяющая степень и алгоритм воздействия коммуникативных импликатур в социальных сетях и блогах на различные сферы общественной жизни (см. рисунок 2):

На данном рисунке представлены различные виды влияния коммуникативных импликатур, которые коррелируют между собой, а именно, как посредством «бытовой», так и при помощи «официальной» коммуникаций адресанты способны воздействовать на адресатов, об- 
Влияние коммуникативных импликатур в социальных сетях и блогах на различные сферы общественной жизни
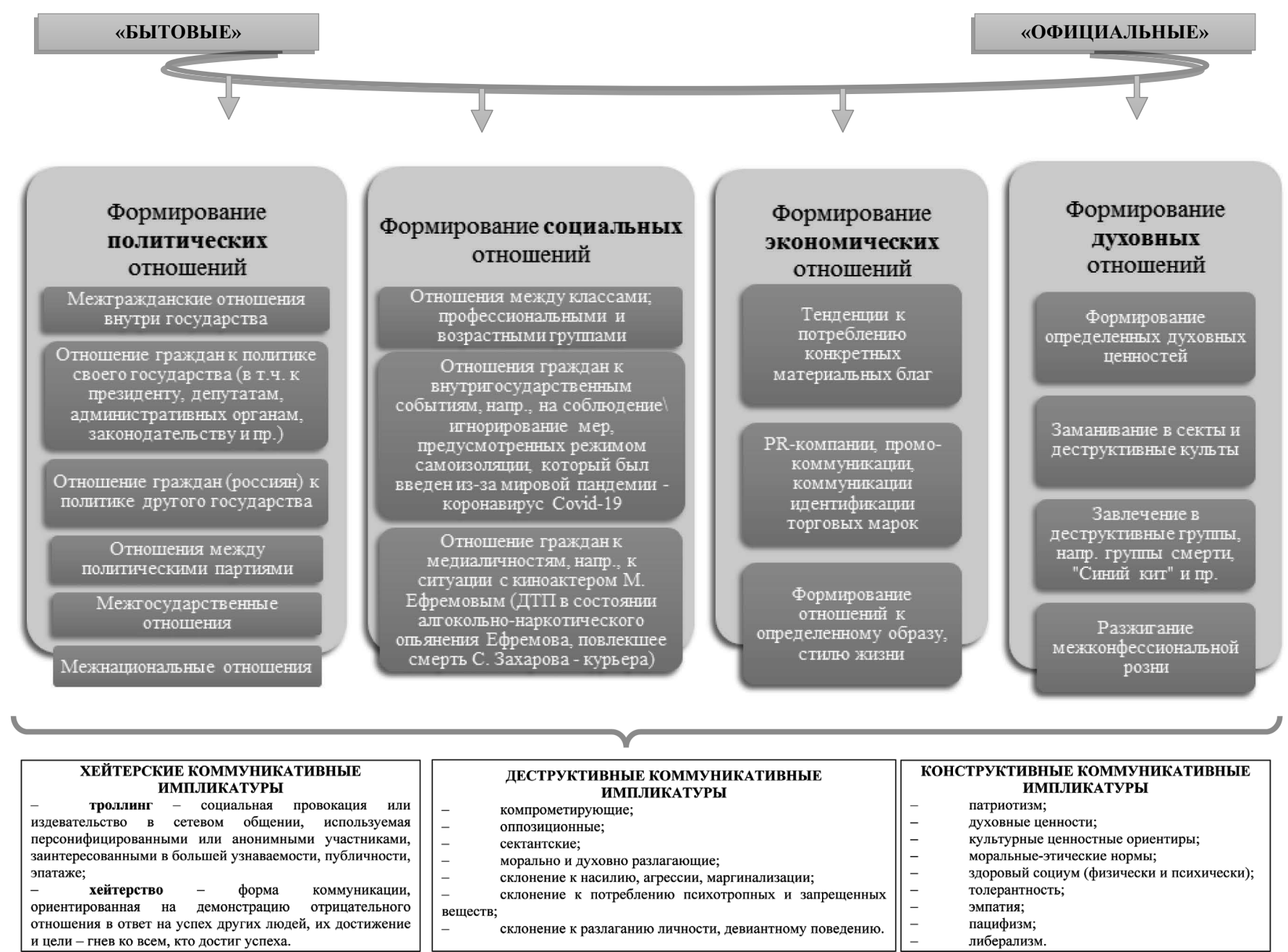

\begin{tabular}{|c|c|c|}
\hline $\begin{array}{l}- \\
- \\
- \\
- \\
- \\
- \\
\text { веществ } \\
-\end{array}$ & $\begin{array}{l}\text { ДЕСТРУКТИВНЫЕ КОММУНИКАТИВНЫЕ } \\
\text { ИМПЛИКАТУРЫ } \\
\text { компрометирующие; } \\
\text { оппозиционные; } \\
\text { сектантские; } \\
\text { морально и духовно разлагающие; } \\
\text { склонение к насилию, агрессии, маргинализации; } \\
\text { склонение к потреблению психотропных и запрещенных } \\
\text { в; } \\
\text { склонение к разлаганию личности, девиантному поведению. }\end{array}$ & \begin{tabular}{ll} 
& \multicolumn{1}{c}{ КОНСТРУКТИВНЫЕ КОММУНИКАТИВНЫЕ } \\
& \multicolumn{1}{c}{ ИМПЛИКАТУРЫ } \\
- & патриотизм; \\
- & духовные ценности; \\
- & культурные ценностные ориентиры; \\
- & моральные-этические нормы; \\
- & здоровый социум (физически и психически); \\
- & толерантность; \\
- & эмпатия; \\
- & пацифизм; \\
- & либерализм.
\end{tabular} \\
\hline
\end{tabular}

Рис. 2. Виды влияния коммуникативных импликатур в социальных сетях и блогах на различные сферы общественной жизни (рисунок автора)

ращаясь к различным типам отношений. Например, при формировании политических отношений, инициируются определенные тенденции касательно конкретного образа жизни, национальностей или взаимоотношений между конфессиями, при этом целеполагание сообщений адресантов может иметь как негативные, так и позитивные коннотации, а модели убеждающих импликатур при этом могут иметь как ложное, так и истинное значение.

Ярким примером служит эпидемиологическая ситуация с пандемией коронавируса Covid-19, которая спровоцировала массовые кривотолки, имеющие самые различные цели: от убеждения в целесообразности оптовых закупок антисептических средств и средств индивидуальной защиты (коммерческий интерес), до попыток спровоцировать массовую истерию и сынициировать компрометирующие действия граждан против правительства Российской Федерации (далее - РФ), а также призвать выступить против поправок к Конституции РФ [6], подписание которых всё же состоялось, на- помним, 02 июля 2020 года.

Ввиду вирулентного воздействия на массовое сознание фейковой информации, активно распространяемой в социальных сетях и блогах, о ситуации с эпидемиологической обстановкой, на территории России введена уголовная и административная ответственность за распространение заведомо ложной информации о коронавирусе или «недостоверно общественно значимой информации» (ФЗ от 01.04.2020 №99-Ф3 ст. 6.3 КоАП РФ, ст. 13.15 КоАП РФ [11], и ФЗ от 01.04.2020 №100-Ф3 ст. 207.1 и ст. 207.2 УК РФ [10]). Принятие данных поправок в Конституции РФ заставило адресантов-оппозиционеров обратиться к другой форме информационного оружия убеждающим коммуникативным импликатурам с имплицитным контекстом.

Исходя из концепции И.Ю. Хандархаевой (2015), существуют определенные модели убеждающей коммуникации, агрегирующие в себе два основополагающих 
момента: (1) как правило, убеждение, выступает в роли попытки социального воздействия, выражающее намерение адресанта или группы адресантов модифицировать или произвести какие-либо изменения мнения адресата / группы адресатов; (2) основным способом реализации данного намерения является коммуникация. «Главным же отличием убеждения от других форм социального воздействия является акцент на сообщении, содержащем аргументы» [13, с. 49]. Полагаем, в виртуальном общении могут быть использованы как эксплицитные (выражающиеся в прямых номинациях, оценочных суждениях и пр.), так и имплицитные коммуникативные импликатуры - в зависимости от целеполагания адресантов. Тем не менее, согласно психологическим аспектам, реципиент не приемлет прямые способы воздействия, тем более, от неизвестных ему адресантов, поэтому отправители обращаются к имплицитной семантике убеждения.

Рассмотрим информальную корреляцию коммуникативных импликатур на конкретных примерах, отражающих, каким образом декомпозированные нами сферы формирования отношений (см. рис. 2) влияют друг на друга в социальных сетях. Например, в настоящий момент (июль, 2020 год) в блогах и мессенджерах активно распространяется информация, провоцирующая граждан выступить против законопроекта, касающегося дистанционного обучения [12]. Однако, когда адресаты просят прокомментировать данную информацию, адресанты не способны привести логических доводов, аргументирующих оппозиционное мнение. Более того, при внимательном прочтении данного документа наблюдается отсутствие отсылок к тем изменениям, которые нанесут ущерб российской системе образования, новые идеи по развитию дистанционного образования в стране предусмотрены с сохранением традиционной формы обучения, что подчеркивает недостоверность распространяемых коммуникативных импликатур. В качестве примера представим скриншоты двух разных групп в WhatsApp, где коммуниканты призывают проголосовать против инноваций:

Согласно сообщениям на рисунках 3 и 4, адресанты

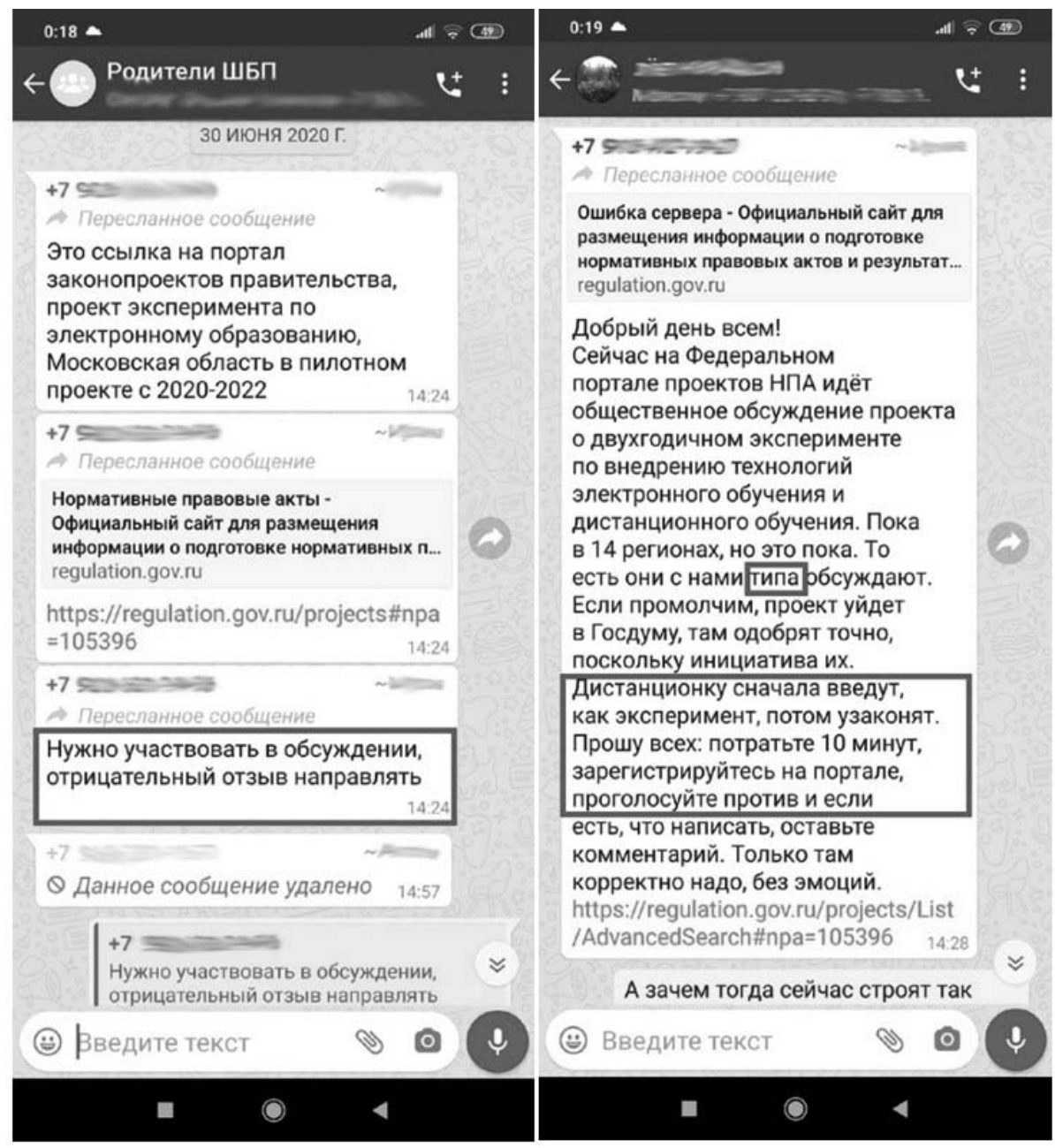

Рис. 3 и 4. Провокации, касающиеся принятия поправок в законе о реализации образовательных программ с применением электронного обучения и дистанционных образовательных технологий 
просят выступить против поправок, не аргументировав своего мнения. Также видно, что это пересланные сообщения, соответственно, они имеют массовое распространение. Что характерно, в первой виртуальной группе 61 коммуникант, во второй - 39 участников, полагаем, среди них нашлись лица, которые бездумно выступили против поправок и переслали вышеупомянутые сообщения другим лицам. При этом при просьбе пояснить, в каком именно разделе данные адресанты увидели поправки, гласящие, что всё обучение станет дистанционным и будет реализовано на удаленной основе, отправители сообщения воздержались от комментариев, т.к. данная информация в ФЗ от 29.12.2012 № 273-Ф3 ст. 16 [12] отсутствует.

Таким образом, в коммуникативных импликатурах «Нужно участвовать в обсуждении, отрицательный отзыв направить» и "Дистанционку сначала введут, как эксперимент, потом узаконят... проголосуйте nротив...» можно проследить тенденции оппозиции против власти РФ (согласно рис. 2 речь идет о формировании политических отношений в переписке «бытового» характера), коррелирующие с формированием социальных аспектов, касающихся отношений граждан к внутригосударственным событиям (см. рис. 2).

Далее рассмотрим пример медицинской статьи о коронавирусе Covid-19 под заголовком «Коронавирус Соvid-19. Только актуальная и достоверная информация. Доказательная медицина для всех» [7] (далее - «Коронавирус (ovid-19»), в которой посредством коммуникативных импликатур адресанты пытаются в теме о пандемии призвать реципиентов не верить в эпидемиологическую обстановку в мире, выступить против принятия поправок в Конституции РФ [6], нарушать режим самоизоляции, пренебрегать мерами предосторожности и индивидуальной защитой, а также утверждают, что в рядах высшего коллегиального исполнительного органа государственного управления существует заговор против россиян, подчеркивают, что СМИ нагнетают обстановку и держат население в страхе ради выгоды (неизвестной этиологии), заявляют о вирулентности предпринимаемых карантинных мер и пр. Практически все дифференцированные нами отношения, формируемые посредством коммуникативных импликатур (политические, социальные, экономические - см. рис. 2) фигурируют в комментариях при обсуждении медицинской статьи о коронавирусе.

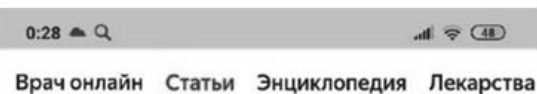

Врачонлайн Статьи Энциклопедия Лекарства

Medspecial

Коронавирус COVID-19.

Только актуальная и достоверная информация

\section{5 марта 2020 | 38 (4) 455 тыс}

\begin{tabular}{l}
\hline ВАЖНО! Мы собираем всю достоверную \\
информацию по СОVID-19. Основные \\
источники информации: uptodate, СDC, \\
ВОЗ. Статья обновляется и редактируется. \\
Рекомендуем поместить ссылку на данную \\
статью в закладки или следить за \\
обновлениями.
\end{tabular}

ВАЖНО2!: с 25.03.2020 в Москве, пациентам с легкой формой COVID-19 разрешили болеть дома. Правила поведения дома мы описали здесь

В декабре 2019 года в Китае, провинции Ухань, зарегистрирована вспышка атипичной (необычной) пневмонии, вызванной неизвестным возбудителем.

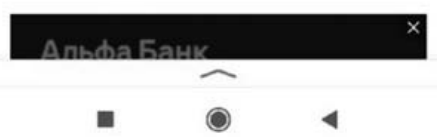

Рис. 5. Заявление редакции Medspecial.ru о том, что информационный контент достоверен

При исследовании официального сайта Medspecial.ru «Доказательная медицина для всех», где информация проверяется врачами (об этом гласит первый абзац статьи на скриншоте), многие адресаты интуитивно начинают доверять написанному, в том числе, комментариям после статьи о пандемии. Однако профессионалами и модераторами проверяются на достоверность только сами статьи, но не комментарии читателей, которые, при соблюдении простых этических норм, могут писать любое свое мнение касательно вышесказанного.

В данном сообщении первый адресант заявляет о том, что пандемии не существует: «Этой пандемии и не было!», чем провоцирует читателей, не способных мыслить критически и обладающих конспирологическим сознанием, игнорировать предписания режима самоизоляции, не доверять медикам и мерам, предпринимаемым правительством РФ, связанным с мировой эпидемиологической обстановкой. Второй участник беседы нагнетает ситуацию посредством коммуникативной импликатуры: «В Kитае новая вспышка», а именно, в то время, когда официальными источниками стала распространяться информация о том, что в Китае пандемия побеждена и, соответственно, в России также в ближайшем 
времени наступит благоприятная эпидемиологическая обстановка, смысл данной коммуникативной импликатуры заключается в том, что ситуация безысходна и население обречено болеть еще очень долго, т.К. даже в КНР поле долгой борьбы медиков и правительств, коронавирус Covid-19 вновь стал прогрессировать. Третье сообщение: «кт облучение иммунитет стресс антибиотики могут убить» на рис. 6 призывает население не делать КТ (компьютерную томографию органов грудной полости (КТ легких) - важное лабораторное исследование на Covid-19, результаты которого являются одними из самых достоверных показателей наличия / отсутствия заболевания), контекст высказывания ложно гласит, что КТ - это радиоактивное облучение организма, которое снижает и без того ослабленный коронавирусом иммунитет и нейтрализует действие лекарственных препаратов. Тем самым, адресант подвергает риску здоровье и жизни читателей.

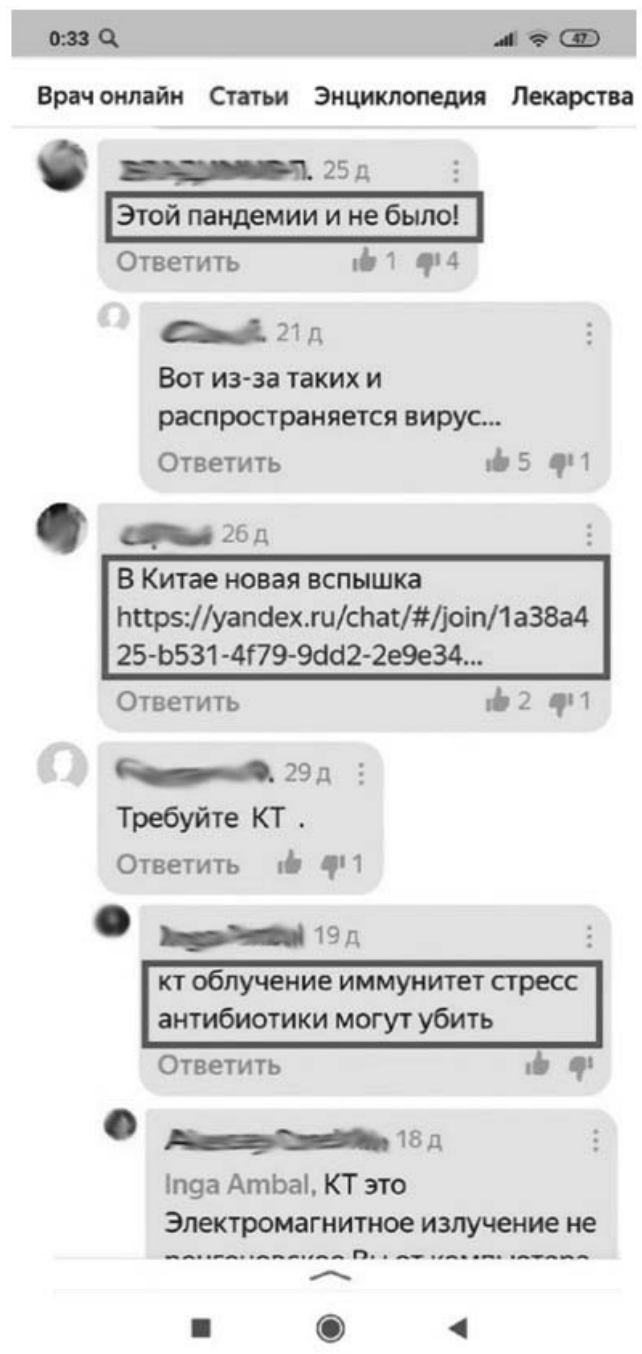

Рис. 6. Комментарии к статье «Коронавирус Covid-19»

Коммуникативная импликатура: «Вирус, конечно есть, но не страшнее гриппа. Нам говорят, что много умирают... Но среди моих знакомых нет зараженных...» говорит о том, что коронавирус Covid-19 болезнь неопасная, соответственно, власти обманывают россиян и зря вводят режим самоизоляции, при этом адресант аргументирует свой вывод тем, что у него «нет заболевших знакомых».

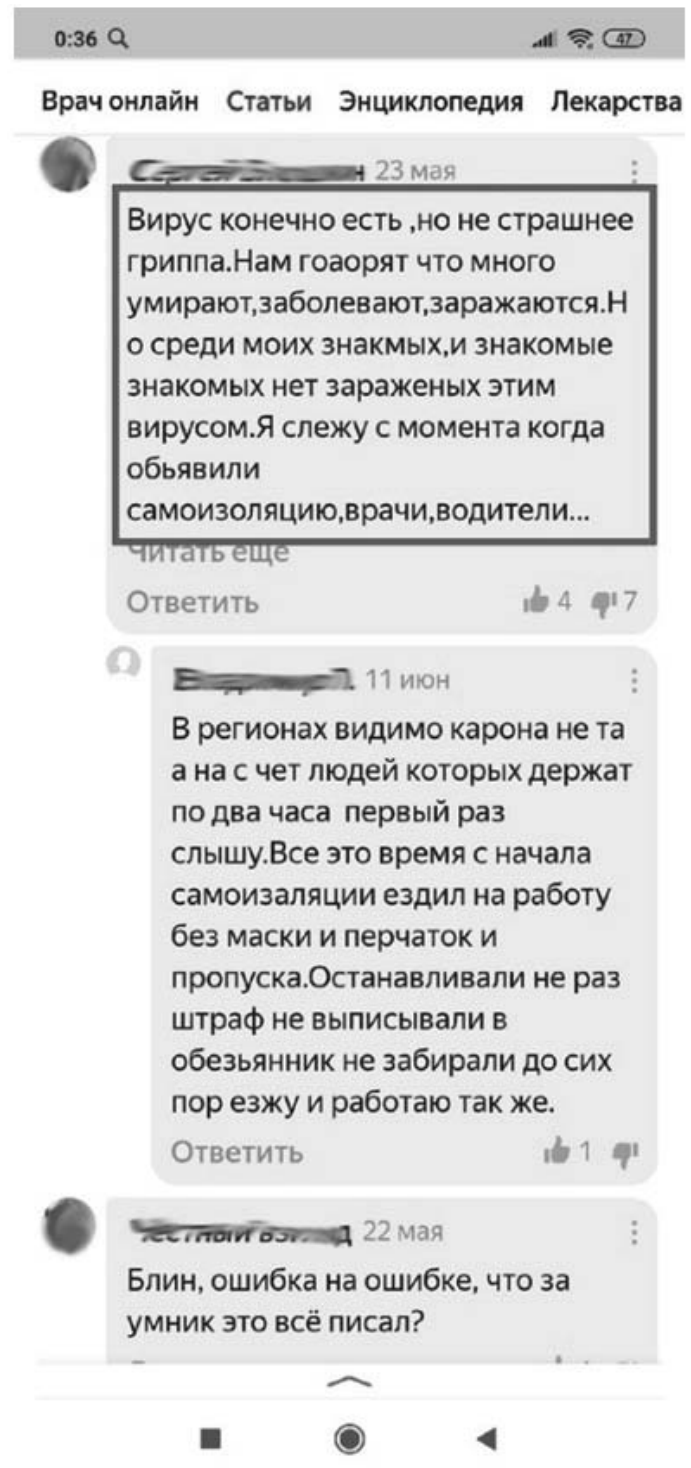

Рис. 7. Комментарии к статье «Коронавирус Covid-19»

На рисунке 8 коммуникант заявляет о недостоверности сведений, освещаемых официальными СМИ и, соответственно, о методах манипулирования общественностью: «СМИ постоянно нагнетают обстановку...». В данной коммуникативной импликатуре прослеживается попытка формирования социальных отношений, а именно, деструктивного отношения граждан к внутригосударственным событиям. 


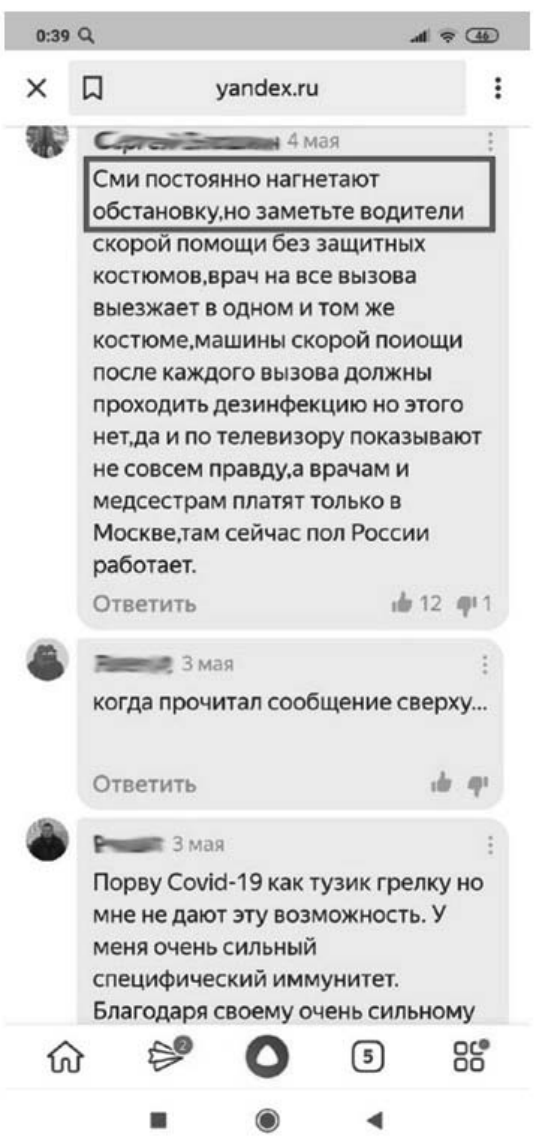

Рис. 8. Комментарии к статье «Коронавирус Covid-19»

Напомним о том, что ВО3 (Всемирная организация здравоохранения) призывает в обязательном порядке весь мир во время пандемии Covid-19 носить средства индивидуальной защиты (медицинские маски) [15]. Однако на рисунке 9 адресант подвергает под сомнение данную концепцию: «Написано же по-русски: «На сегодняшний день достоверных данных о влиянии масок на заболеваемость нет». Следующий участник беседы категорически опровергает актуальность ношения медицинских масок посредством импликатуры: «Сейчас маски - это мода и способ заработка», полагая, что данное индивидуальное средство защиты используется только в коммерческих целях (формирование экономических отношений - тенденции к потреблению конкретных материальных благ, см. рис. 2).

На следующем скриншоте (см. рис. 10) продолжается обсуждение целесообразности ношения медицинских масок для предотвращения распространения вируса. Коммуникативная импликатура «Во всем мире носят маски!» ориентирована на убеждение реципиентов в том, что данное средство защиты от Covid-19 актуально. Однако оппонент-провокатор пытается доказать свою правоту, ссылаясь на невнимательность коммуниканта посредством импликатуры: «Читаем между строк: масок нет, потому и эффрективность не доказана». Далее этот же адресант критически высказывается в адрес правительства и их неблагонадежности посредством коммуникативной импликатуры: «Масок нет... nотому, что доблестное государство не хочет их купить», - здесь прилагательное «доблестное» имеет негативную коннотацию, тем самым, участник беседы подчеркивает несостоятельность правительственных структур, которые действуют таким образом «из вредности», а не по иным более серьезным причинам.

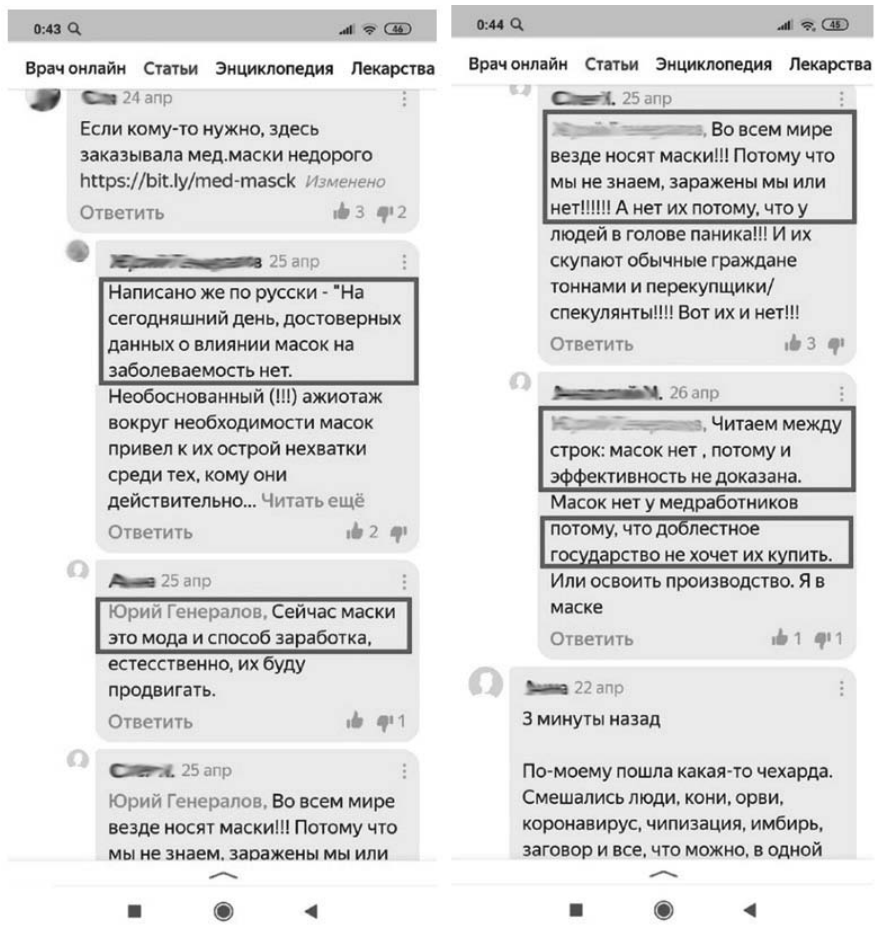

Рис. 9 и 10. Комментарии к статье «Коронавирус Covid-19»

Далее (см. рис. 11) идет продолжение той же беседы, которая отображена на рисунках 9 и 10. Комментарии к статье про коронавирус стали затрагивать поправки к Конституции РФ 2020 года [6]: «А потом пойдем как всегда дружными рядами проголосуем за Конституцию и обнуление, и за Бог знает что еще», - согласно данному высказыванию, приближается момент принятия поправок в Конституции РФ которые, по мнению адресанта, способны нанести вред народонаселению России. Следующий адресант (рис. 11) пытается донести информацию о том, что руководство Министерства науки и высшего образования РФ и Министерства здравоохранения РФ не справились с задачей предугадать и предотвратить распространение пандемии Covid-19, тем самым, усугубив эпидемиологическую ситуацию в России, очевидно, сравнивая подход к науке и медицине вышестоящих инстанций с опытом прошлых лет, намекая, что в СССР врачи и ученые справились бы с данной ситуацией грамотнее и оперативнее. 


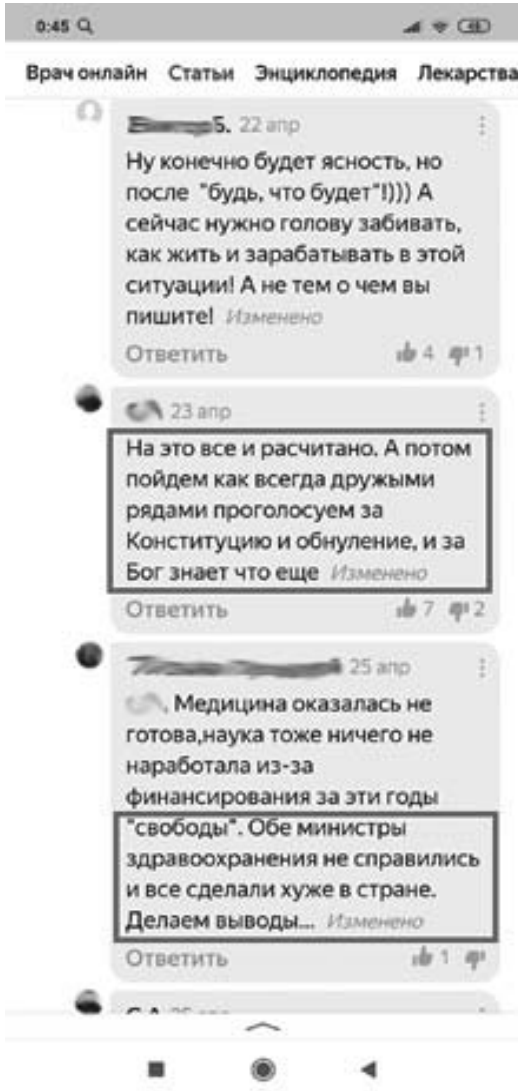

Рис. 11. Комментарии к статье «Коронавирус Covid-19»
На следующих рисунках №12, 13 и 14 представлены три скриншота, где производится попытка одного адресанта убедить участников блога в мировом заговоре против населения с целью запугать людей:

О том, что адресант (это один и тот же человек, вступивший в виртуальный полилог с разными участниками беседы) сообщает о «Теории заговора» свидетельствуют следующие коммуникативные импликатуры: (1) «Обычный грипn, которым болеют люди каждый год»" (умаление масштаба проблемы пандемии Covid-19); (2) «А в «афрриканских странах» и нет этого вируса, он есть там, где люди не довольны», (3) «А там (полагаем, в Африке прим. автора) почему то и нет этого вируса, вирус есть там, где не доволен народ!» и (4) «Прочент высок там, где недоволен народ!» - смысл данных высказываний заключается в том, что, по мнению оппозиционера, в Африканских странах нет коронавируса, так как, очевидно, там местные жители довольны своей жизнью, а в России Covid-19 «выдумало» или «внедрило» правительство РФ с целью снизить процент недовольных россиян, которых не устраивают действия административных органов; коммуникативной импликатурой (4) «Прочент высок там, где недоволен народ!», -адресант пытается сказать, что высокий процент заболеваемости коронавирусом Covid-19 фиксируется в тех странах, где граждане настроены против политики государства, намекая, в первую очередь, на Россию; (5) «И вы верите СМИ, очнитесь,

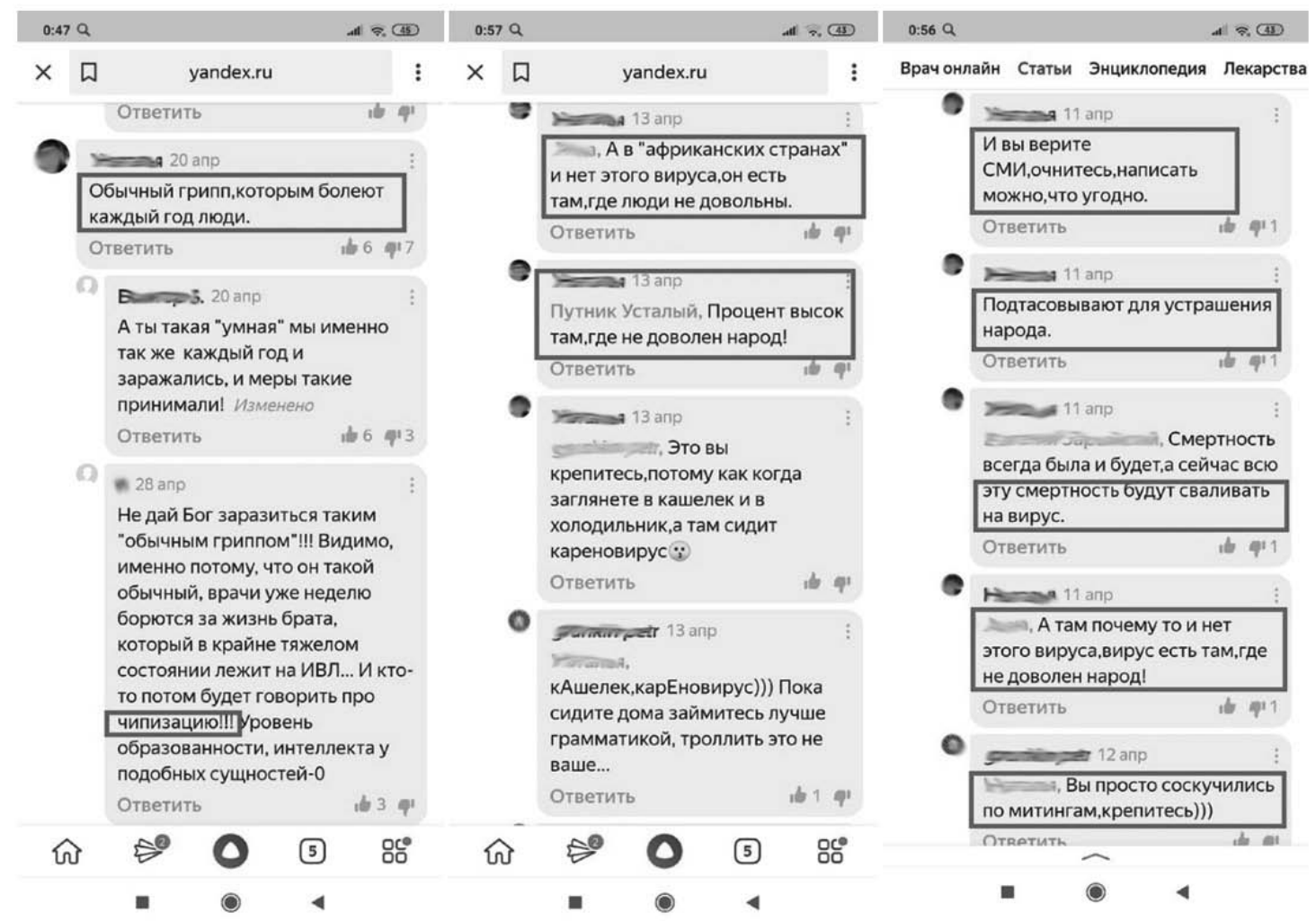

Рис. 12, 13 и 14. Комментарии к статье «Коронавирус Covid-19» 
написать можно, что угодно», - заявление о том, что СМИ бесконтрольно распространяет ложную информацию, которую не контролирует цензура; (6) «Подтасовывают для устрашения народа», - импликатура говорит о том, что правительство пытается запугать своих граждан посредством подтасовок ложных данных о высоком риске и проценте заболеваемости коронавирусной инфекцией 2019-nCoV; (7) «Смертность была и будет, а сейчас эту смертность будут сваливать на вирус», - адресант полагает, что статистика смертности не выходит за рамки обычной, только правительство зачем-то пытается приписать ее негативному воздействию коронавируса Covid-19. Коммуникативная импликатура другого адресанта «И кто-то потом будет говорить про чипизацию!!! Уровень образованности, интеллекта у подобных сущностей - 0» - это ответ коммуниканту-оппозиционеру, чьи высказывания мы рассмотрели выше. Говоря о чипизации, адресант имеет ввиду «Теорию заговора», предполагающую посредством прививок от коронавируса Covid-19 ввести чипы в каждого гражданина, которые позволят отслеживать перемещение человека и, тем самым, вторгаться в его личную жизнь. Однако оппонент предыдущего адресанта настроен критично к мнению о чипизации, так как в тексте своего сообщения рассказывает о реальности коронавируса и тяжелом течении заболевания; также несогласие с «Теорией заговора» подчеркнуто коммуникативной импликатурой «Уровень образованности, интеллекта у подобных сущностей - 0» - смысл данного высказывания заключается в том, что «Теория заговора» - это фейк, а те, кто в него верит - глупые и недальновидные люди. Импликатура: «Вы просто соскучились по митингам, крепитесь)))» адресована участнику беседы, который заверял в ложности общественно значимой информации о Covid-19, методах работы государственных структур и данных, предоставляемых СМИ. Имплицитная семантика насмешки данного высказывания (в совокупности с использованием эмоджи) говорит о том, что автор иронично относится к мнению оппонентки и причисляет ее к людям, кто склонен митинговать не ради справедливости и истины, а с целью развлечься, отдохнуть, повеселиться. Смысл слова «крепитесь» означает, что пандемия и, соответственно, режим самоизоляции вскоре закончатся и участница беседы сможет вернуться к своему привычному образу жизни, заключающемуся в бессмысленных митингах и восстаниях.

Стоит отметить, что нами намеренно сохранена В цитатах орфография и пунктуация, с целью продемонстрировать неграмотность адресанта-оппозиционера чем человек менее образован, тем он менее способен думать критически, соответственно, относится к типу людей с конспирологическим типом мышления. Вернемся к рисунку 13, где коммуникативная импликатура «кАшелек, карЕновирус))) Пока сидите дома займитесь лучше грамматикой, троллить это не ваше...» также подчеркивает безграмотность адресанта-провокатора.
Данное высказывание призывает участника беседы сосредоточиться на собственном самообразовании, пока введен режим самоизоляции и люди находятся продолжительное время дома, поэтому имеют возможность использовать свободное время более рационально, чем тратить его на троллинг.

Анализ представленных нами коммуникативных импликатур позволил прийти к двум заключениям: (1) виртуальные коммуникативные импликатуры отличны от тех, которые используются людьми при прямом общении; (2) нами выделено три типа адресантов, чьи коммуникативные импликатуры в социальных сетях и блогах выступают в роли инструмента психологическиинформационной войны, а именно: (1) суггесторы - те, кто внушает заведомо ложную, общественно значимую информацию намеренно, с целью разрушить гражданственно-политические взаимоотношения внутри страны (России) по приказанию и инструкции внешнеполитических и/или внутриполитических врагов; (2) конспирологи - люди с параноидальным расстройством личности или люди, не способные критически мыслить, предполагающие, что они являются жертвами мирового заговора и пытающиеся убедить в реальном существовании данного заговора других коммуникантов, чтобы их «спасти» от негативных последствий политических интриг - данный тип адресантов склонен более доверять фейковой информации, чем официальным источникам (СМИ, научным фактам, профессиональным изданиям и пр.); (3) хейтеры (тролли) - адресанты, получающие удовольствие от того, что вводят реципиентов в заблуждение, панику, провоцируют массовую истерию. Все три типа адресантов активно способствуют распространению ложной информации в социальных сетях и блогах.

Полагаем, что использование коммуникативных импликатур в психолого-информационной войне гораздо эффективнее других средств виртуальной убеждающей коммуникации, что обусловлено следующими аспектами:

(1) безнаказанность - в то время как ложные новости и другая недостоверная общественно значимая информация благодаря работе компьютерных алгоритмов помогает найти первоисточник и привлечь к уголовной или административной ответственности автора, который прямым текстом искажал представления читателей о том или ином событии, коммуникативные импликатуры предельно проблематично интерпретировать конкретным образом ввиду их двусмысленного толкования и имплицитности, а также найти посредством хештегов, как в ситуации с фейковыми новостями.

(2) примитивность - коммуникативные импликатуры ориентированы на «простоту общения», которое, в отличие от официальной информации, вселяет в сознание людей больше доверия. Читатели склонны верить фейковым данным, даже до- 
ходящим до абсурда, из-за привычки не доверять официальным источникам. Данная тенденция обусловлена превалированием среди россиян ранее сформированными установками на недоверие и конспирологическим сознанием, онтология которых проистекает из-за гнёта репрессивных методик правления (преимущественно) Сталина. Ввиду вышеперечисленных факторов «люди неспособны мыслить критически... Кроме того в условиях кризиса и стресса в теории заговора начинают верить больше людей» [5]. Таким образом, пользователи полагают, что такой же «простой» гражданин, как и они, желает донести до общественности истину. В то время как официальные источники и СМИ (по мнению многих граждан), призваны публиковать материал под «диктовку» правительства, и делают из обывателей жертв политических интриг, «простой» адресант не работает на вышестоящие инстанции, а попросту делится достоверной информацией;

(3) отсутствие цензуры - в социальных сетях и блогах достаточно сложно проследить все нарушения в содержании и распространении различного контента, тем более если коммуникация происходит в закрытых группах или в личной переписке, где имеют место также перепосты различных сообщений (спама или фейковой концепции). Если обсуждение происходит в открытом источнике, модераторы удаляют сообщения, эксплицитно оскорбляющие чью-либо личность, но не отвечают за достоверность высказываний.

На основании приведенных данных исследований можно сделать следующие выводы:

1. Если ранее коммуникация в социальных сетях и блогах имела примитивный характер и обеспечивала обмен информацией «бытового плана», то в настоящий момент она имеет более конструктивное значение и способна выступать в роли информационно-психологического оружия.

2. Коммуникативные импликатуры являются одним из стратегических и тактических инструментов психолого-информационного оружия, ориентированного на воздействие в виртуальном дискурсе на мнение пользователей и, преимущественно, сосредоточены на массовых социально ориентированных коммуникациях.

3. Существует различие между пропозицией, выраженной высказыванием, и передаваемыми коммуникативными импликатурами. На первый взгляд коммуникативные импликатуры киберпространства характеризуются транспарентностью и конвенциональностью, однако, в то же время, среди множества проанализированных примеров определенно присутствует имплицитность высказываний.

4. Изначально теория Грайса строилась на концеп- ции, что для того, чтобы знать, что говорящий на самом деле хотел выразить посредством конкретного высказывания, необходимы две вещи: во-первых, знание диапазона возможных смыслов высказывания и конкретного спектра его возможных референтов; во-вторых, понимание того, какой смысл и референцию говорящий намеревался заложить в данном случае. В настоящий момент при общении в Интернет-пространстве посредством блогов и социальных сетей данный лингвистический феномен стал приобретать новые черты, позволяющие понять задумку адресанта и по иным критериям. При виртуальной коммуникации среди пользователей могут быть как знакомые личности, так и люди, которые никогда в жизни друг друга не знали и не встретятся в будущем. Тем не менее, сетевые ресурсы наполнены общими темами, позволяющими понимать коммуникативные импликатуры, даже если они представлены не в тексте, посвященном конкретной проблематике. Например, при обсуждении статьи про пандемию Covid-19 коммуниканты обсуждали ложность представляемой информации СМИ, теорию мирового заговора, поправки в Конституции РФ 2020 года, неблагонадежность властей и пр. При этом все участники виртуальной беседы понимали, о чем идет речь в том или ином высказывании.

5. Определено влияние коммуникативных импликатур в Интернет-пространстве на различные сферы общественной жизни (политическую, социальную, экономическую и духовную) и дифференцированы типы влияний коммуникативных импликатур на реципиентов (хейтерские, деструктивны и конструктивные).

6. Авторами выделено три типа адресантов, чьи коммуникативные импликатуры выступают в роли инструментов психолого-информационной войны, дезинформирующих пользователей социальных сетей и блогов: (1) суггесторы - те, кто намеренно внушает заведомо ложную, общественно значимую информацию в военно-политических целях по приказанию внутриполитических и внешнеполитических врагов российского государства; (2) конспирологи - люди с параноидальным расстройством личности или люди, не способные критически мыслить; (3) хейтеры (тролли) - адресанты, получающие удовольствие от создаваемых ими скандалов и интриг в виртуальном пространстве.

7. Эффективизация использования коммуникативных импликатур в психолого-информационной войне детерминирована тремя основополагающими факторами: (1) безнаказанность (доказать истинный смысл коммуникативной импликатуры, имеющей имплицитный характер, достаточно проблематично); (2) примитивность (фейковые 
данные и новости достаточно большим количеством россиян воспринимаются как истина, в отличие от официальных источников, что обусловлено конспирологическим сознанием, недостатком информации, неразвитым критическим мышлением или его отсутствием многих граждан, ранее сформировавшимися установками на недоверие, что усугубляется в условиях кризиса и стресса); (3) отсутствие цензуры (модераторы, как правило, проверяют информацию, в том числе, в блогах и в социальных сетях, на наличие оскорблений эксплицитного характера, а в некоторых случаях, даже допускают обсценную лексику, но не отвечают за достоверность высказываний виртуальных коммуникантов).

\section{ЛИТЕРАТУРА}

1. Арапова, Н.П. Социально-информациологический подход к теории информационных войн: [монография] / Н.П. Арапова; под общ. ред. А.В. Шевченко; Российская акад. гос. службы при Президенте Российской Федерации. - Москва: Изд-во РАГС, 2007. - 147 с.

2. Гостев, А.А. Глобальная психоманипуляция [Текст]: психологические и духовно-нравственные аспекты / А.А. Гостев; Институт психологии РАН. - Москва: Ин-т психологии РАН, 2017. - 466 с.

3. Гранов, А.Е. Ликвидация безграмотности в первые годы советской власти. Научные труды магистрантов Гуманитарного факультета [Текст] / Министерство науки и высшего образования Российской Федерации, Федеральное государственное бюджетное образовательное учреждение высшего образования «Воронежский государственный педагогический ун-т». - Воронеж: Воронежский государственный педагогический университет, 2015. - Вып. 7. - С. $6-11$.

4. Драгалина-Черная, Е.Г. Следование правилу: рассуждение, разум, рациональность [Электронный ресурс]. - СПб.: Алетейя, 2014. - 452 с.

5. Кекова, Ю. Психолог объяснила, почему люди верят фейкам. Комсомольская правда. Статья от 31.03.2020. URL: https://www.kp.ru/online/news/3817975/. Дата обращения: 14.07.2020.

6. Конституция Российской Федерации (принята всенародным голосованием 12.12.1993 с изменениями, одобренными в ходе общероссийского голосования 01.07.2020).

7. Коронавирус Covid-19. Только актуальная и достоверная информация. Доказательная медицина для всех. URL: https://medspecial.ru/for_ patients/20/31260/. Дата обращения: 14.07.2020.

8. Скрытые смыслы в языке и коммуникации: сборник статей / [Российский гос. гуманитарный ун-т, Ин-т лингвистики; [ред.-сост. И.А. Шаронов]. - Москва: [б. и.], 2008. -246 c.

9. Темиргазина, 3.К. Современные теории в отечественной и зарубежной лингвистике [Электронный ресурс]. - 2-е изд., стер. - Москва: Флинта, 2015. $120 \mathrm{c}$.

10. Федеральный закон от 01.04.2020 № 100-Ф3 «0 внесении изменений в Уголовный кодекс Российской Федерации и статьи 31 и 151 Уголовно-процессуального кодекса Российской Федерации».

11. Федеральный закон от 01.04.2020 № 99-Ф3 «0 внесении изменений в Кодекс Российской Федерации об административных правонарушениях».

12. Федеральный закон от 29.12.2012 № 273-Ф3 (ред. от 08.06.2020) «06 образовании в Российской Федерации» (с изм. и доп., вступ. в силу с 01.07.2020). Статья 16. Реализация образовательных программ с применением электронного обучения и дистанционных образовательных технологий.

13. Хандархаева, И.Ю. Речевое воздействие в рекламе [Текст]: учебно-методическое пособие / И.Ю. Хандархаева; Министерство образования и науки Российской Федерации, Бурятский государственный университет. -Улан-Удэ: Изд-во Бурятского госуниверситета, 2015. - 79 с.

14. Carston, R. (2012) Implicature and Explicature / R. Carston, A. Hall. URL: https://www.researchgate.net/publication/265483734_Implicature_and_Explicature. Date: 13.07 .2020 .

15. Coronavirus disease (COVID-19) advice for the public: When and how to use masks. World Health Organization. URL: https://www.who.int/emergencies/diseases/ novel-coronavirus-2019/advice-for-public/when-and-how-to-use-masks. Date: 14.07.2020.

16. Giles, K. (2016) Handbook of Russian Information Warfare. NATO Defense CollegeCollège de Défense de l'OTAN. - 90 p.

17. Gricean. Conversational Implicatures. LX 502 - Semantics I. 0ct 2, 2008. - Pp. 1 - 7. URL: https://www.bu.edu/linguistics/UG/course//x502/_pages/schedule. html.

18. Implicature (2005) Stanford Encyclopedia of Philosophy. URL: https://plato.stanford.edu/entries/implicature/. Date: 13.07.2020.

19. Moeschler, J. (2012) Conversational and conventional implicatures. URL: https://www.researchgate.net/publication/260319066_Conversational_and_ conventional_implicatures.

20. Nordquist, R. (2020) Conversational Implicature Definition and Examples. ThoughtCo. URL: https://www.thoughtco.com/conversational-implicature-speechacts-1689922/ Date: 13.07.2020.

21. Rooy, R. (2003) Conversational Implicatures and Communication Theory. Text, Speech and Language Technology book series (TLTB, volume 22). - Pp. 283 - 284.

22. Smirnov, M., Malejacq R. (2015) Information War in the Internet. the Conflict Which Cannot Be Won. - 78 p.

23. Wilson, D., Sperber D. (1981) On Grice's theory of conversation. Conversation and Discourse, Edition: 1, Publisher: Croom Helm, Editors: Paul Werth, pp.155-178.

() Петросян Гаяне Оганесовна (11ga1978@mail.ru).

Журнал «Современная наука: актуальные проблемы теории и практики» 